Available online at GSC Online Press Directory

GSC Biological and Pharmaceutical Sciences

e-ISSN: 2581-3250, CODEN (USA): GBPSC2

Journal homepage: https://www.gsconlinepress.com/journals/gscbps

(RESEARCH ARTICLE)

\title{
Inhibitory effects of tuber extract of nut grass (Cyperus rotundus L) on the growth of rat fetuses
}

\author{
Busman Hendri ${ }^{1}$, Nurcahyani Nuning ${ }^{1}$, Farisi Salman ${ }^{1}$, Kanedi Mohammad ${ }^{1, *}$ and Prabiwi Dita Mauliana ${ }^{2}$ \\ ${ }^{1}$ Department of Biology, Faculty of Mathematics and Sciences, University of Lampung, Bandar Lampung, Indonesia. \\ ${ }^{2}$ Faculty of Medicine, University of Lampung, Bandar Lampung, Indonesia.
}

Publication history: Received on 02 November 2019; revised on 13 January 2020; accepted on 16 January 2020

Article DOI: https://doi.org/10.30574/gscbps.2020.10.1.0207

\begin{abstract}
In this paper we studied the effect of tuber extract of nutgrass (Cyperus rotundus l.) on fetal weight and length of white rat (Rattus novergicus) Sprague Dawley. Pregnant female rats $(n=24)$ are grouped into four consisted of six rats each. Group-1 (control) only received distilled water. Group-2, 3 and 4 consecutively received tuber extract of nut grass at the dose of 22.5, 45, and $90 \mathrm{mg} / \mathrm{kg}$ body weight. Extract was given orally using gavage needle on day 6 th for 13 days until day 18th of pregnancy. On day 18th of pregnancy, female rats were lapartomized under deep anaesthesia. All fetuses were taken to measure their body weight and length. The results showed that both fetal weight and fetal length of the rats were significantly decreased with increasing doses of the extract. In conclusion, tuber extract of nut grass (Cyperus rotundus l.) exhibited inhibitory effects against fetal growth of rats during pregnancy.
\end{abstract}

Keywords: Fetal growth; Nutgrass; Cyperus rotundus; Teratogenic

\section{Introduction}

Pregnancy defined as the process of embryo formation and development within the female body. The process includes the influx and migration of spermatozoa, conception, the growth of embryo, implantation, formation and growth of the placenta, and growth and development of the fetus[1].

During pregnancy, fetal growth and development as well as the health status of the mother are greatly affected by maternal dietary intake[2].The use of drugs during pregnancy, for instance, can seriously affect fetal growth and development. In many cases, drugs exposure during the critical period of skeletaldevelopment causes growth retardation (a teratogenic disorder) on limb [3].

Dwarfism, characterized by the lower body weight and length compared to normal, is a common teratogenic disorder occurs in foetuses exposed to teratogenic agents during organogenesis. Teratogenic agents have many sources in nature, including those from plants that are commonly seen as safe and commonly used as traditional medicine [4,5].

One of the plants that is widely used as traditional medicine by people in many Asian countries but is thought to contain teratogenic phytochemicals is nutgrass (Cyperus rotundus L.) [6]. The nutgrass tuber is reported to be efficacious as antifungal, anti-inflammatory, antidiabetic, antidiarrheal, cytoprotective, antimutagenic, antimicrobial, antibacterial, antioxidant, cytotoxic, analgesic and antipyretic. Phytochemical studies showed that the nutgrass tuber contains alkaloids, flavonoids, tannins, starch, glycosides, furochrome, saponins and sesquiterpenoids [7, 8].

\footnotetext{
${ }^{*}$ Corresponding author

E-mail address: wegayendi@yahoo.com
} 
Despite its medicinal efficacy, nut grass herbs are also reported to cause side effects. Long term uses of this grass herb cause fertilization impairment in mice $[9,10]$. This grass tuberis rich in flavonoids. This phytochemical is known to act like antiestrogenic receptors, if fetuses exposed to this compound bone retardation may occur, resulted in imperfect growth of the fetus $[11,12]$.

Coumarin is another pythochemical contained in the nutgrass tuber. This compound is known to have a hepatotoxic effect on human and animals when given continuously. Consumption of coumarin is known to increase abnormalities of the liver functions $[13,14]$. Quercetin is the next other chemical known to have anti-inflammatory and antiviral activities. This compound also cause toxic effects and interfere with the physiological process of the body and has a biphasic effect on the development of cancer cells $[15,16,17]$.

Tuber extract of nut grass also known to contain $\mathrm{p}$-hydroxybenzoic acid, $\beta$-sitosterol, $\beta$-D-glucopyranoside are also found in the extracts of the nut grass. These compounds are reported to be teratogenic and cause abortion in female mice [18].

Given the nutgrass (Cyperus rotundus L.) extract contains substances that are suspected of teratogenic, we have investigated its inhibitory effects on the growth of fetuses in laboratory rats (Rattus norvegicus).

\section{Material and methods}

\subsection{Plant samples and extraction}

Plant samples of nutgrass (Cyperus rotundus L.)collected from the District of Tanggamus, Lampung. Fresh tubers of the grass were washed and sun dried. Then the dried tubers were ground to be a powder form. By using Soxhlet apparatus the powder was extracted with alcohol 96\% (Reg No.GBL 8109032909A1, Batch No. C910 202) as the solvent. Extraction carried out at the temperature of $35^{\circ} \mathrm{C}$ and the rotation of $60 \mathrm{rpm}$ for 60 minutes.

\subsection{Experimental animals}

Female rats (Rattus norvegicus) Sprague Dawley aged 12-16 weeks and weight of 200-250 g, were obtained from Lampung Veterinary Center, Indonesia. All animals were housed at the temperature of $25^{\circ} \mathrm{C}$ and $12: 12$-hour light-dark cycle with free access to water and pellets ad libitum. All animal care and treatment procedures were approved by the Ethics Committee, Faculty of Medicine, University of Lampung, Indonesia.

\subsection{Experimental design and treatment}

One the test rats $(n=24)$ got pregnant, the animals grouped into four consisted of six rats each. Group-1 (control) only received distilled water. Group-2, 3 and 4 consecutively received tuber extract of nut grass at the dose of 22.5 , 45, and $90 \mathrm{mg} / \mathrm{kg}$ body weight. Extract was given orally using gavage needle on day 6th for 13 days until day 18th of pregnancy.

\subsection{Fetal size measurement}

On day 18th of pregnancy, female rats were lapartomized under deep anaesthesia. All fetuses were removed and washed using distilled water. After being dried with using tissue paper, the fetal length and weight were measured using calliper and Mettler Toledo Analytic Balance, respectively.

\subsection{Statistical analysis}

The data are presented as mean \pm SD and analyzed statistically using a one-way ANOVA. least significance difference (LSD) test was used as the post hoc test.

\section{Results and discussion}

The effects of tuber extract of nut grass (Cyperus rotundus L.) on body weight of rat fetuses are presented in Figure 1. Analysis of variance of the data in Figure 1 resulted in F value of 9.7747 (lower 3.0725 - upper 4.8740). 


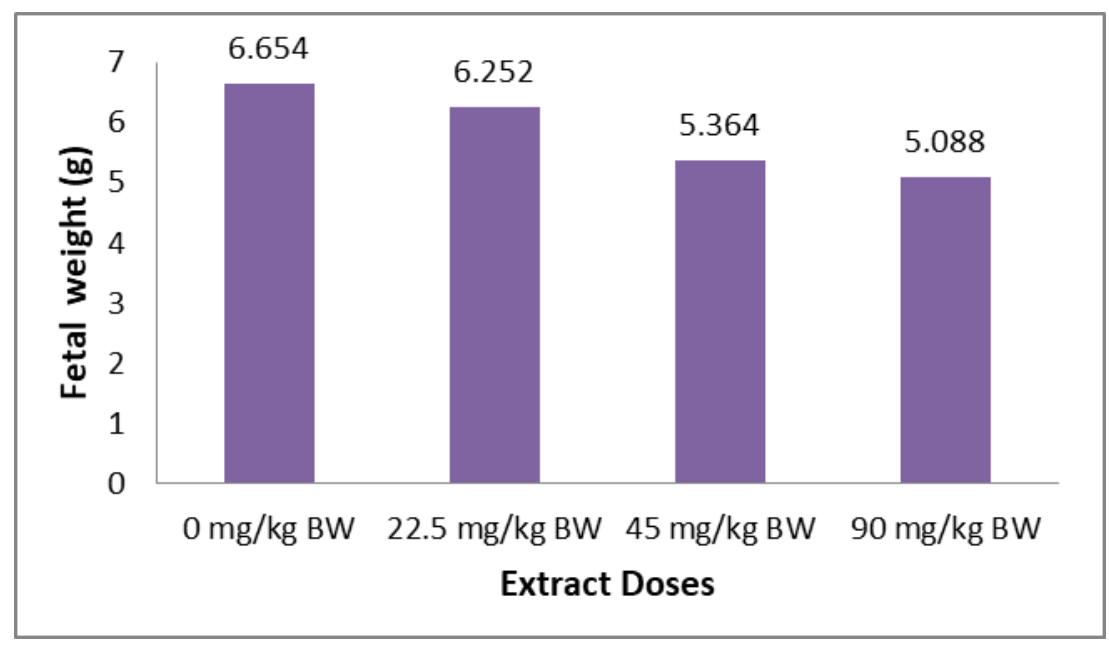

Figure 1 Effects of tuber extract of nut grass (Cyperus rotundus L.) on the fetal weight of rat

Results of post hoc test using LSD (Least Significant Difference) against the mean weight values of the fetuses are shown in Table 1 below.

Table 1 LSD test results against mean difference of fetal weight of rats given tuber extract of nut grass

\begin{tabular}{|c|c|c|c|c|c|}
\hline $\begin{array}{l}\text { Extract } \\
\text { doses }\end{array}$ & Mean & \multicolumn{3}{|c|}{ Difference } & $\begin{array}{l}\text { Critical difference } \\
\text { (lower - upper) }\end{array}$ \\
\hline $0 \mathrm{mg} / \mathrm{kg}$ & 6.654 & & & & \\
\hline $22.5 \mathrm{mg} / \mathrm{kg}$ & 6.252 & 0.402 & & & $0.6919-0.9568$ \\
\hline $45 \mathrm{mg} / \mathrm{kg}$ & 5.364 & $1.29^{* *}$ & $0.888^{*}$ & & \\
\hline $90 \mathrm{mg} / \mathrm{kg}$ & 5.088 & $1.566^{* *}$ & $1.164^{* *}$ & 0.276 & \\
\hline
\end{tabular}

Figure 2 shows the fetal length of rat given tuber extract of nut grass (Cyperus rotundusL.). F value of the ANOVA against the data resulted in $\mathrm{F}=9.3929$ (lower 3.0725 - upper 4.8740).

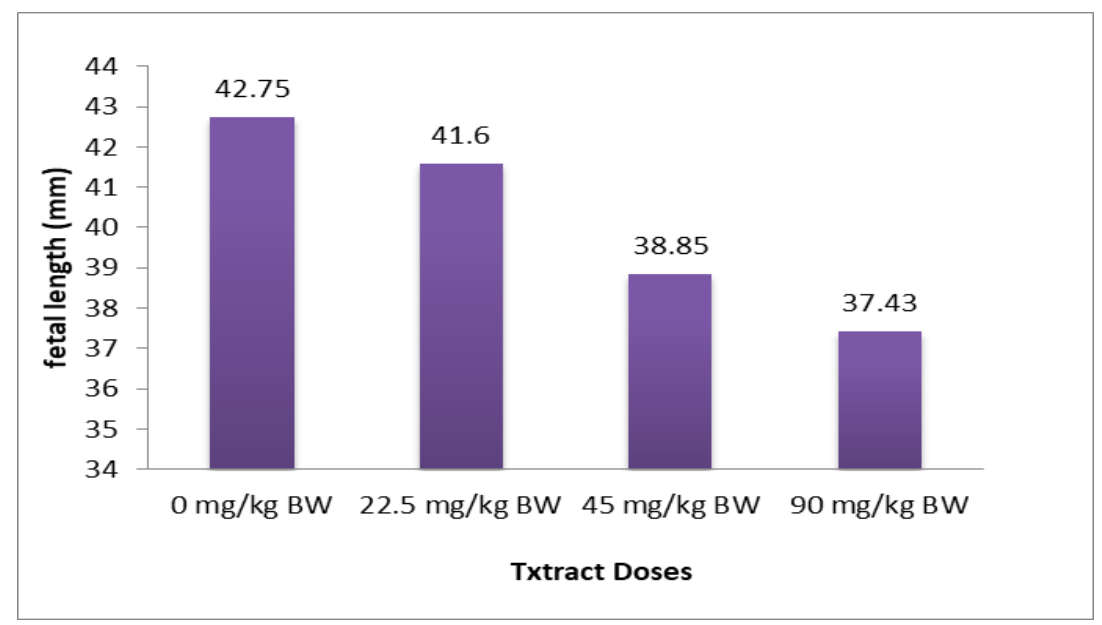

Figure 2 Effects of tuber extract of nut grass (Cyperus rotundus L.) on the fetal length of rat

LSD test against the difference of mean values of the fetal length shown in Figure 2 are presented in Table 1 below. 
Busman et al. / GSC Biological and Pharmaceutical Sciences, 2020, 10(01), 059-064

Table 2 LSD test results against mean difference of fetal length of rats given tuber extract of nut grass.

\begin{tabular}{|c|c|c|c|c|c|}
\hline $\begin{array}{l}\text { Extract } \\
\text { doses }\end{array}$ & Mean & \multicolumn{3}{|c|}{ Difference } & $\begin{array}{l}\text { Critical difference } \\
\text { (lower - upper) }\end{array}$ \\
\hline $0 \mathrm{mg} / \mathrm{kg}$ & 42.67 & & & & \\
\hline $22.5 \mathrm{mg} / \mathrm{kg}$ & 41.746 & 0.924 & & & $2.5303-3.4992$ \\
\hline $45 \mathrm{mg} / \mathrm{kg}$ & 38.778 & $3.892^{* *}$ & $2.968^{*}$ & & \\
\hline 90 mg/kg & 37.27 & $5.4^{* *}$ & $4.476^{* *}$ & 1.508 & \\
\hline
\end{tabular}

The research findings indicate clearly that tuber extract of nut grass (Cyperus rotundus L.) has inhibitory effects on the growth of rat foetuses. Phytochemical study revealed that nut grass contains quercetin and flavonoids in their tubers. Quercetin is known to have a toxicity effect in cells. This compound is known to react in inhibiting tyrosine kinase receptors. Receptor tyrosine kinases are known to be receptors of growth factor [19, 20, 21].

Flavonoids in the roots of the nutgrass are also known to have cytotoxic effects. Because flavonoids are also compounds that can be used as anticancer, flavonoids also have very strong side effects. This is because flavonoids work by apoptosis and suppress cells with high proliferation, such as the bone marrow $[22,23,24]$.

Anticancer compounds such as flavonoids and saponins are thought to inhibit osteoprogenitor cell division so that the formation of osteoblasts is disrupted and consequently the absorption of calcium by these cells becomes inhibited [25].

In a previous study, the effect of the puzzle grass tuber extract (Cyperus rotundus L.) in pregnant mice resulted in malformations in the fetal body parts of the mouse (Mus musculus) accompanied by a decrease in the thickness of the chondrocyte reserve zone, proliferation zone and bone maturation zone fetus mice (Mus Musculus). Meanwhile, the thickness of the zone is an important parameter of bone formation or body frame development [26].

During pregnancy, there are several factors that can affect the baby's weight, namely maternal factors, placental factors, fetal factors and environmental factors. One of the maternal factors that influence baby's weight is the presence of teratogens during pregnancy [27].

Decreasing fetal weight is the mildest form of exposure to a compound that is teratogenic. Weight loss is an indicator of the occurrence of growth barriers due to interference with the processes that underlie growth (cell division, metabolism and synthesis) $[28,29,30]$.

In humans, estrogen has an important role in fat metabolism. Estrogen is known to inhibit lipolysis in fat metabolism. WhereasCyperus rotundus is plant that rich in flavonoids. This phytochemical is an agonist and antagonist in the estrogen receptor (antiestrogenic). Therefore, if the fetus is exposed to antiestrogenic compounds from the grass extract, there will be bone retardation and weight loss $[31,32]$.

\section{Conclusion}

Because of both body weight and body length of rat foetuses are significantly lower by the higher doses of extract, it can be concluded that tuber extract of nut grass (Cyperus rotundus L.) has inhibitory effects on the growth of rat foetuses during pregnancy.

\section{Compliance with ethical standards}

\section{Acknowledgments}

Authors thank the laboratory staffs at the Department of Biology, University of Lampung, for their support in plant sample preparation and storage, caring for test animal. 


\section{Disclosure of conflict of interest}

This article is not the object of any conflict of interest and has not been submitted to other journal for publication. Consequently, we authorize the journal to publish it.

\section{Statement of ethical approval}

The experimental protocol were applied in accordance with the ethical norms approved by the Ethics Committee for Medical and Health Research the Faculty of Medicine, University of Lampung, appointed by the dean Decree No. 155/UN26/8/KP/2014.

\section{References}

[1] Manuaba I, Manuaba C and Manuaba F. (2010). Ilmu Kebidanan, Penyakit Kandungan dan KB edisi 2. Jakarta: Buku Kedokteran EGC.

[2] Marangoni F, Cetin I, Verduci E, Canzone G and Giovannini M. (2016). Maternal diet and nutrient requirement in pregnancy and breastfeeding. Nutrients, 8(10), 629.

[3] Katzung B. (2014). Basic and Clinical Pharmacology. United States of America: McGraw-Hill Education.

[4] Pace LE. (2012). Balancing Acts: safe and evidence-based prescribing for women of reproductive aged. Women's health, 8(4), 415-425.

[5] Costa KC, Bezerra SB, Norte CM, Nunes LM and Olinda TM. (2012). Medicinal plants with teratogenic potential: current considerations. Brazilian Journal of Pharmaceutical Sciences, 48(3), 427-433.

[6] Parsons WT and Cuthbertson EG.(2001). Noxious Weeds of Australia. Second Edition. CSIRO Publishing, Collingwood, Melbourne.

[7] Lawal OA and Oyedeji AO. (2009). Chemical composition of the essential oils of Cyperus rotundus L. from South Africa, J Molecules, 14(8), 2909-2917.

[8] Busman H, Nurcahyani N, Sutyarso and Kanedi M. (2018). Chemical composition of the essential oils distilled from tuber of rumput teki (Cyperus rotundus Linn.) growing in Tanggamus, Lampung, Indonesia. European J of Biomedical and Pharm Sciences, 5(4), 69-72.

[9] Nurcahyani N, Wirasti Y, Busman H and Jamsari. (2016). Fetal skeleton development of mice (Mus musculus L) threated with nutgrass (Cyperus rotundus) extract. J ISFA. 2, 245-252.

[10] Rabbani M, Ghannadi A and Malekian N. (2014). Evaluation of the effect of Cyperus rotundus in scopolamineinduced learning deficit in mice. Adv Biomed Res. 3, 217.

[11] Collins-Burow BM, Antoon JW, Frigo DE, Elliott S, Weldon CB and Boue M. (2012). Antiestrogenic activity of flavonoid phytochemicals mediated via the c-Jun N-terminal protein kinase pathway: Cell-type specific regulation of estrogen receptor alpha. J. Steroid Biochemistry and Molecular Biology. 132(1-2), 186-193.

[12] Shiezadeh F, Mousavi SH, Sadegh Amiri M, Iranshahi M and Tayarani-Najaran Z. (2013). Cytotoxic and apoptotic potential of Rheum turkestanicum janisch root extract on human cancer and normal cells. Iranian Journal Pharmaceutical Research, 12(4), 811-819.

[13] Abraham K, Wohrlin F, Lindner O, Heinemeyer G and Lampen A. (2010). Toxicology and risk assessment of coumarin: Focus on human data. Jurnal Mol Nutr Food Res, 228-239.

[14] Iwata N, Kainuma M, Kubota T, Sugawara N and Ozono S. (2016). The relation between hepatotoxicity and the total coumarin intake from traditional Japanese medicines containing cinnamon bark. J Frontiers in Pharmacology. 7(1), 1-9.

[15] Li Y Yao J, Han C, Yang J and Chaudhry MT. (2016). Quercetin, inflammation and immunity. J Nutrients. 8(3), 114.

[16] Selin-Rani S, Senthil-Nathan S, Thanigaivel A, Vasantha-Srinivasan P and Edwin ES. (2016). Toxicity and physiological effect of quercetin on generalist herbivore, spodoptera litura fab. and a non-target earthworm Eisenia fetida Savigny. J Chemosphere. 165, 257-267.

[17] Van der Woude H. (2006). Mechanisms of toxic action of the flavonoid quercetin and its phase II metabolites [thesis]. Netherland: Wageningen Universiteit. 
[18] Saraswathy A and Vidhya B. (2013). Phytochemical investigation of the tender shoot of Bambusa bamboos (Linn.) voss. J. Pharmacognosy and Phytochemistry, 1(5), 52-56.

[19] Nidugala H, Avadhani R and Prabhu A. (2016). In vitro cytotoxic activity of rhizome extracts of Cyperus rotundus (L.) against colon carcinoma and Ehrlich ascites carcinoma. J. Applied Pharmaceutical Science. 6(11), $172-175$.

[20] Maruyama I. (2014). Mechanism of activation of receptor tyrosine kinases: monomer or dimer. Cells, 3(2), 3014330.

[21] Muha V and Muller HA. (2013). Function and mechanism of fibroblast growth factor (FGF) signalling in Drosophilla malanogaster. Int J. Mol Sci, 14(2), 5920-5937.

[22] Borek C. (2001). Antioxidant health effects of aged garlic extract. J. Nutrition, 131, 1010S-1015.

[23] Lin Y, Shi R and Shen HM. (2009). Luteolin, a flavonoid with potentials for cancer prevention and therapy. Curr Cancer Drug Targets, 8(7), 634-646.

[24] Susianti. (2015). Potensi rumput teki (Cyperus rotundus L.) sebagai agen antikanker. Jurnal Prosiding Artikel Ilmiah Dies Natalis FK Unila ke 52-57.

[25] Astika. (2000). Penelitian Hayati vol. 5 No. 2. Surabaya: PBI Komisariat Surabaya.

[26] Kini U and Nandeesh BN. (2012). Physiology of bone formation, remodeling and metabolism: Radionuclide and Hybrid Bone Imaging. Berlin: Springer-Verlag Berlin Heidelberg. 29-55.

[27] Roland M, Friis CM, Godang K, Bollerslev J and Haugen G. (2014). Maternal factors associated with fetal growth and birthweight are independent determinant of placental wight and exhibit differential efeects by fetal sex. Plos One. 9(2).

[28] Capra L, Tezza G, Mazzei F and Boner AL. (2013). The origin of health and disease; the influence of maternal diseases and lifestyle during gestation. Ital J Pediatr. 39, 7.

[29] Emily R, Graham DL, Money KM and Stanwood G. (2015). Developmental consequences of fetal exposure to drugs: what e know and what we still must learn. Neuropsycho-pharmacology. 40(1), 61-87.

[30] Wilson PD, Feuston MH and Kerstetter S. (1990). Teratogenicity of 2-methoxyethanol applied as a single dermal dose to rats. Fundam Appl Toxicol, 15, 448-456.

[31] Lugilo HF. (2014). Estrogen and body weight regulation in women: The role of estrogen receptor alpha on adipocyte lipolysis. Acta Med Indones. 46(4), 333-8.

[32] Busman H, Yanwirasti, Jamsari, Tjong DH and Kanedi M. (2016). Antiestrogenic effect of tuber extract of Cyperus rotundus, on tke endometrial thickness of mice (Mus musculus L). World J Pharm and Life Science, 2(6), 341347.

\section{How to cite this article}

Busman H, Nurcahyani N, Farisi S, Kanedi M and Prabiwi DM. (2020). Inhibitory effects of tuber extract of nut grass (Cyperus rotundus L) on the growth of rat fetuses. GSC Biological and Pharmaceutical Sciences, 10(1), 59-64. 